\title{
Biological response of pulps submitted to different capping materials
}

\section{Resposta biológica de polpas submetidas a diferentes materiais capeadores}

\author{
André Luiz Fraga Briso* \\ Vanessa Rahal** \\ Sandra Rahal Mestrener* \\ Eloi Dezan Junior***
}

\begin{abstract}
Pulp capping is a procedure that comprises adequate protection of the pulp tissue exposed to the oral environment, aiming at the preservation of its vitality and functions. This study evaluated the response of the dental pulps of dog teeth to capping with mineral trioxide aggregate (MTA) or calcium hydroxide P.A. For that purpose, 37 teeth were divided into two groups, according to the capping material employed. Two dogs were anesthetized and, after placement of a rubber dam, their pulps were exposed in a standardized manner and protected with the experimental capping materials. The cavities were then sealed with resin-modified glass ionomer cement and restored with composite resin. After sixty days, the animals were killed and the specimens were processed in order to be analyzed with optic microscopy. It was observed that MTA presented a higher success rate compared to calcium hydroxide, presenting a lower occurrence of infection and pulp necrosis.
\end{abstract}

DESCRIPTORS: Dental pulp capping; Biocompatible materials; Calcium hydroxide.

RESUMO: O capeamento pulpar é um procedimento que consiste na adequada proteção do tecido pulpar exposto ao meio oral, objetivando a preservação de sua vitalidade e suas funções. O objetivo deste trabalho foi observar a resposta da polpa dental de cães ao capeamento com o agregado de trióxido mineral (MTA) ou hidróxido de cálcio P.A. Para tanto, 37 dentes foram divididos em dois grupos, de acordo com o material capeador utilizado. Dois cães foram anestesiados e após o isolamento absoluto do campo operatório, realizou-se exposição padronizada da polpa, proteção com os materiais capeadores testados e selamento das cavidades com cimento modificado de ionômero de vidro. Os dentes foram então restaurados com resina composta. Após sessenta dias, os animais foram sacrificados e as peças foram processadas para a análise microscópica dos dentes. Observou-se que o MTA apresentou maior índice de sucesso em relação ao hidróxido de cálcio, evidenciando menor ocorrência de infecção e necrose pulpar. DESCRITORES: Capeamento da polpa dentária; Materiais biocompativeis; Hidróxido de cálcio.

\section{INTRODUCTION}

Pulp capping comprises adequate protection of a vital pulp exposed to the oral environment. It is a technique that aims at preserving the vitality of this tissue, thus avoiding more invasive endodontic procedures.

Within this context, a great advancement for the achievement of a biologically acceptable treatment was the advent of a material which has been demonstrated to lead pulp cells to stimulate deposition of a hard tissue bridge fundamentally constituted of granulomatous areas, dystrophic calcification and dentin ${ }^{10,26}$. Some investigators emphasize that the material of choice for achieve- ment of this outcome is calcium hydroxide, and especially calcium hydroxide P.A. ${ }^{12}$.

However, new materials have been employed for the protection of exposed pulps. These include the mineral trioxide aggregate (MTA), whose primary components are tricalcium silicate, tricalcium aluminate, calcium oxide and silicate oxide ${ }^{1}$. This new cement was developed with the chief intention to avoid communication between the pulp and the external environment ${ }^{13}$. On the basis of the excellent results achieved, especially as to the sealing ability $^{1}$ and tissue response, Torabinejad, Chivian ${ }^{24}$ (1999) concluded that MTA may also be applied

\footnotetext{
*PhDs, Assistant Professors, Discipline of Restorative Dentistry; **DDS, Trainee, Discipline of Restorative Dentistry; ***PhD, Assistant Professor, Discipline of Endodontics - Department of Restorative Dentistry, School of Dentistry of Araçatuba, State University of São Paulo.
} 
in several clinical situations, such as pulp capping, internal resorption, apexification, endodontic surgery and for the sealing of perforations. These manners of utilization of MTA are also mentioned in other studies ${ }^{15,19,22,24}$.

So far, it is noticed that this issue, pulp capping, has several aspects that may be questioned, and other experimental histological studies are warranted to improve the existing treatment technique, making it more feasible and reliable.

Thus, this study comprised a histomorphological evaluation of the pulp response of dog teeth sixty days after capping with $\mathrm{Ca}(\mathrm{OH})_{2}$ P.A. or MTA.

\section{MATERIAL AND METHODS}

Before the present study was carried out, its design was submitted to and approved by the Institutional Review Board for Investigations in Animals, School of Dentistry of Araçatuba, State University of São Paulo (UNESP). For the study, thirty-seven teeth of 2 mongrel dogs aged 1 year were employed. After general anesthesia with sodium pentobarbital, rubber dam was placed and the operative field was submitted to antisepsis. Standardized Class V cavities were then prepared on the cervical third of the buccal surface of each tooth with a diamond bur n. 1090 (KG Sorensen Ind. Com. Ltda., Barueri, São Paulo, Brazil). The cavities were deepened and the pulp tissue was exposed in a standardized manner, with $0.5 \mathrm{~mm}$ in diameter, with a diamond bur n. 2173 (KG Sorensen Ind. Com. Ltda., Barueri, São Paulo, Brazil), fabricated especially for this study. The rotary cutting instruments were used at high-speed under thorough cooling with saline solution.

Control of hemorrhage and drying of the exposed pulp were performed with autoclaved cotton and drops of saline solution.

For group I, comprising 19 teeth, the material employed for pulp capping was calcium hydroxide P.A. paste (Reagen, Quimibras Ind. Químicas S/ A - Rio de Janeiro, Rio de Janeiro, Brazil) mixed with saline solution, whereas in the 18 teeth in group II the exposed pulps were directly protected with MTA (Pro Root ${ }^{\circledR}$ - Dentsply, Tulsa, Oklahoma, USA) mixed with saline solution and applied following the manufacturer's instructions. Each dental hemi-arch had one of the tested capping materials, in such a way that the one capped with MTA would always have the antagonist teeth capped with $\mathrm{Ca}(\mathrm{OH})_{2}$.

After the application of the aforementioned materials, the cavities were filled with resin-modi- fied glass ionomer cement Fuji II LC (GC Corporation, Tokyo, Kanto, Japan) and the teeth were restored with composite resin TPH Spectrum (Dentsply - Latin America, Petrópolis, Rio de Janeiro, Brazil). After curing of the ionomeric cement with the Optilux-500 unit (Demetron) for 40 seconds and with luminous intensity of $500 \mathrm{~mW} / \mathrm{cm}^{2}$, the teeth were etched with $37 \%$ phosphoric acid for 20 seconds, and the adhesive system Prime\&Bond 2.1 NT was applied (Dentsply - Latin America, Petrópolis, Rio de Janeiro, Brazil). The resin was, then, inserted in the cavities and light-cured for 40 seconds.

The animals were then kept in captivity under constant observation and receiving a balanced diet: ration and fresh water. Sixty days after treatment, the animals were anesthetized and killed by perfusion of buffered $10 \%$ formalin solution at neutral $\mathrm{pH}$. Then, the hemi-arches were removed, placed in $10 \%$ formalin solution for two weeks and decalcified in 17\% EDTA (Biodinâmica Quím. e Farm. Ltda., Ibiporã, Paraná, Brazil).

After embedding in paraffin, the specimens were serially sectioned. The $6 \mu \mathrm{m}$ thick sections thus obtained were stained with hematoxylin and eosin and by the Brown \& Brenn method.

Analysis of the results were evaluated by one of the authors, according to the criteria described by Mestrener et al. ${ }^{16}$ (2003). The histomorphological data considered received scores 1 to 4 , being 1 the best and 4 the worst outcome, whereas scores 2 and 3 represented intermediate values. These data were submitted to statistical analysis with the Mann-Whitney method.

\section{RESULTS}

The obtained data about the general state of the pulp and hard tissue bridge formation were computed and submitted to statistical analysis with the Mann-Whitney method. It was revealed that the results for group II (MTA) were significantly better than those observed for the $\mathrm{Ca}(\mathrm{OH})_{2}$ group $(\alpha=0.01)$.

Analysis of the sections of the $\mathrm{Ca}(\mathrm{OH})_{2}$ group revealed that, from the 19 treated cases, the dental pulp presented complete hard tissue bridge in 7 cases, with defects in 3 (Figure 1) and deposition only at the lateral walls in 1 specimen. All cases exhibited bridges composed of dentin associated or not to areas of deposition of irregular hard tissue, with thickness ranging from 48 to 480 micrometers. In 4 cases, the bridges were deeply located, 
resembling the aspect observed after performing pulpotomy (Figure 2).

There was also pulp necrosis in 8 specimens, with periapical reaction in 2 of them. The Brown and Brenn staining revealed the presence of Grampositive microorganisms in 9 cases (Figure 3 ). Moreover, 9 specimens exhibited acute inflammatory infiltrate, mostly intense and extensive. Chronic inflammatory infiltrate of variable intensity and extension was found in the 19 cases analyzed. Nine specimens did not display deposition of a hard tissue bridge.

Concerning the performance of MTA, as to the pulp response, a hard tissue bridge was found in 12 of the 18 treated cases, being 6 complete and 6 with minor defects (Figure 4). The thickness of the hard tissue bridges ranged from 16 to 800 micrometers. Concerning morphology, the bridges

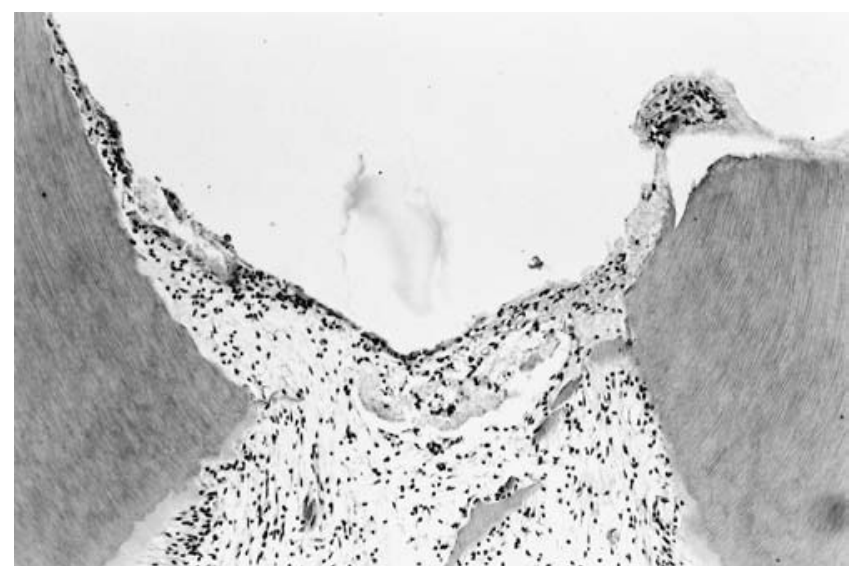

FIGURE 1 - $\mathrm{Ca}(\mathrm{OH})_{2}$ group. Absence of hard tissue bridge. Note dentin fragments within the pulp tissue. H.E. $100 \mathrm{X}$.

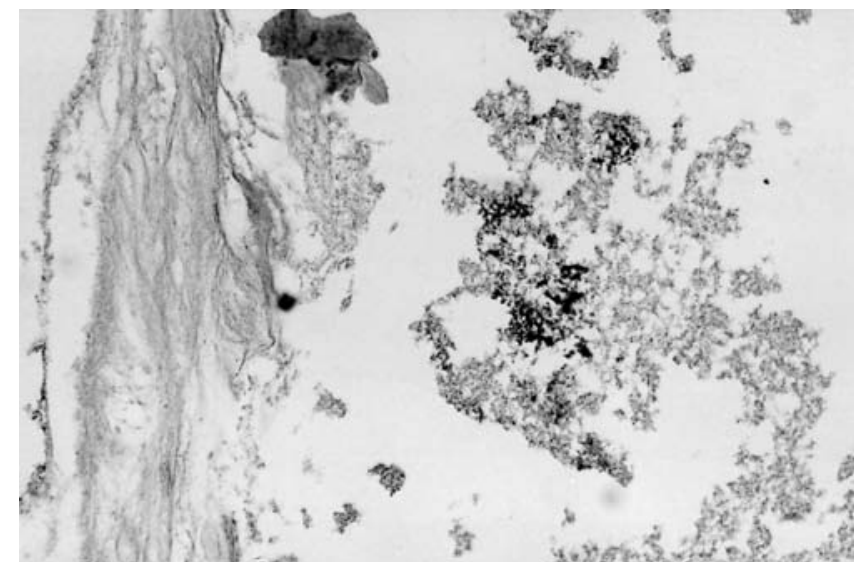

FIGURE 3 - Characteristic aspect of the presence of Gram-positive microorganisms within the necrotic pulp tissue. Brown and Brenn, $200 \mathrm{X}$. were composed of dentin associated or not to areas of deposition of irregular hard tissue. There was no necrosis between the hard tissue bridge and the protection material, suggesting that these structures were always deposited from the capping material; in two cases, there was hard tissue deposition similar to that observed in pulpotomies.

In 3 cases, the dental pulp exhibited necrosis, and in one such case the Brown and Brenn staining revealed the presence of Gram-positive microorganisms. The dental pulp was free of inflammation in 5 specimens. In 9 cases there was chronic inflammatory infiltrate of mild to moderate intensity, only in the coronal pulp. In six such cases there was no deposition of a hard tissue bridge.

Tables 1 and 2 display the results achieved as scores.

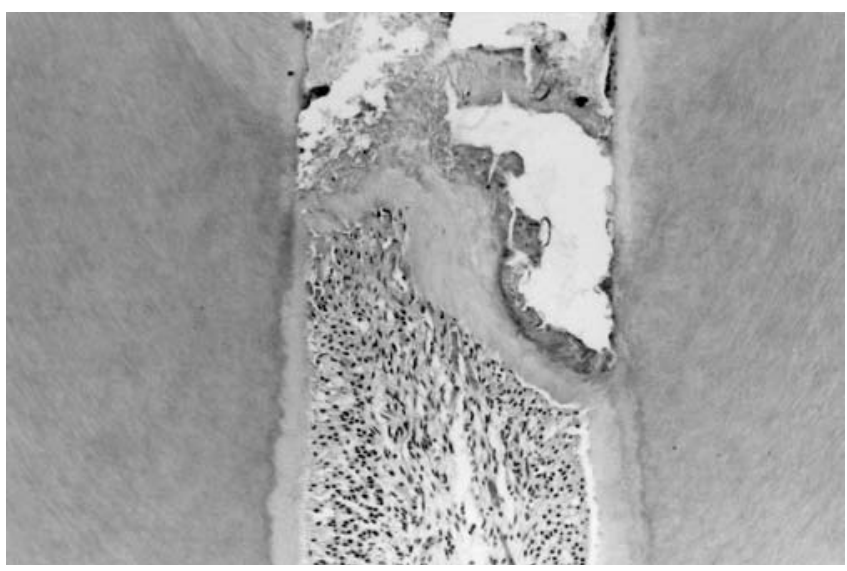

FIGURE 2 - $\mathrm{Ca}(\mathrm{OH})_{2}$ group. A hard tissue bridge, resembling that of a pulpotomy, protects the remaining pulp tissue without inflammatory process. H.E. $100 \mathrm{X}$.

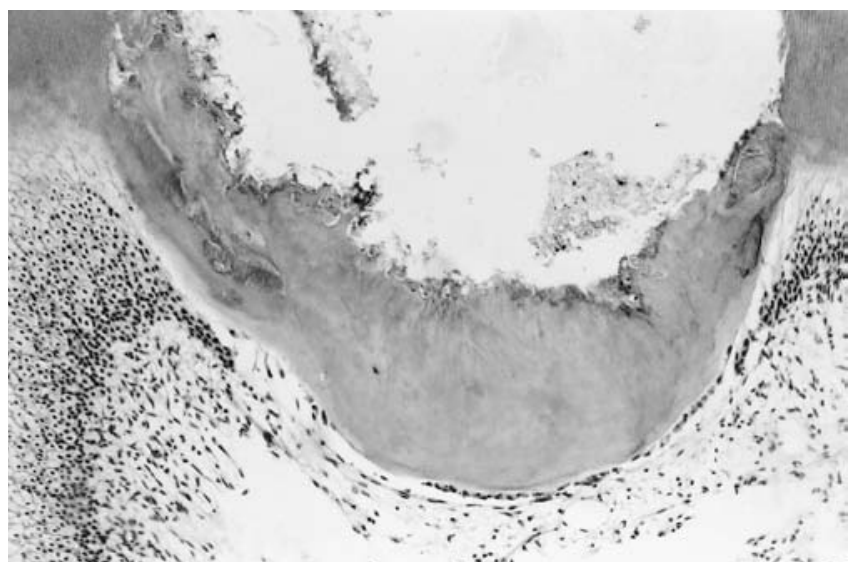

FIGURE 4 - MTA group. Complete hard tissue bridge protects the exposed dental pulp. H.E. $100 \mathrm{X}$. 
Briso ALF, Rahal V, Mestrener SR, Dezan Junior E. Biological response of pulps submitted to different capping materials. Braz Oral Res 2006;20(3):219-25.

TABLE 1 - MTA - Scores assigned to the different histomorphological events observed in the specimens investigated.

\begin{tabular}{|c|c|c|c|c|c|c|c|c|c|c|c|c|c|c|c|c|c|c|c|c|c|}
\hline & & peci & nen $\mathrm{n}$. & 1 & 2 & 3 & 4 & 5 & 6 & 7 & 8 & 9 & 10 & 11 & 12 & 13 & 14 & 15 & 16 & 17 & 18 \\
\hline & & Cor & tinuity & 2 & 1 & 1 & 4 & 4 & 1 & 4 & 4 & 2 & 4 & 4 & 2 & 2 & 2 & 1 & 1 & 2 & 1 \\
\hline$\tilde{D}_{0}^{2}$ & & Mo & phology & 1 & 1 & 1 & 4 & 4 & 1 & 4 & 4 & 1 & 4 & 4 & 1 & 1 & 1 & 1 & 1 & 1 & 1 \\
\hline$\vec{m}$ & & Thi & kness & 3 & 1 & 2 & 4 & 4 & 3 & 4 & 4 & 3 & 4 & 4 & 3 & 3 & 3 & 3 & 1 & 3 & 3 \\
\hline & & Loc & tion & 1 & 3 & 3 & 4 & 4 & 4 & 4 & 4 & 1 & 4 & 4 & 1 & 4 & 1 & 1 & 2 & 1 & 1 \\
\hline & & $\stackrel{\Delta}{=}$ & Intensity & 1 & 1 & 1 & 1 & 1 & 1 & 1 & 1 & 1 & 4 & 4 & 1 & 1 & 1 & 1 & 1 & 1 & 1 \\
\hline & $\underset{\widetilde{\sigma}}{\mathbb{Z}}$ & 定 & Extension & 1 & 1 & 1 & 1 & 1 & 1 & 1 & 1 & 1 & 4 & 4 & 1 & 1 & 1 & 1 & 1 & 1 & 1 \\
\hline & జ్రు & $\stackrel{\circlearrowright}{\stackrel{U}{Z}}$ & Intensity & 2 & 2 & 1 & 3 & 4 & 3 & 3 & 3 & 3 & 4 & 4 & 1 & 3 & 2 & 1 & 1 & 2 & 1 \\
\hline $\overrightarrow{1}$ & モ & 己 & Extension & 2 & 2 & 1 & 3 & 4 & 3 & 3 & 4 & 3 & 4 & 4 & 1 & 3 & 2 & 1 & 1 & 2 & 1 \\
\hline$\stackrel{\vec{Z}}{\vec{U}}$ & & ene & al status & 2 & 2 & 1 & 2 & 4 & 2 & 2 & 2 & 2 & 4 & 4 & 1 & 2 & 2 & 1 & 1 & 2 & 1 \\
\hline & & iant & cells & 1 & 1 & 1 & 1 & 3 & 1 & 1 & 1 & 1 & 4 & 4 & 1 & 1 & 1 & 1 & 1 & 1 & 1 \\
\hline & & orei & n particles & 1 & 1 & 1 & 1 & 3 & 1 & 1 & 1 & 2 & 4 & 4 & 1 & 1 & 2 & 1 & 1 & 1 & 1 \\
\hline & & acte & & 1 & 1 & 1 & 1 & 1 & 1 & 1 & 1 & 1 & 4 & 1 & 1 & 1 & 1 & 1 & 1 & 1 & 1 \\
\hline
\end{tabular}

TABLE 2 - $\mathrm{Ca}(\mathrm{OH})_{2}$ - Scores assigned to the different histomorphological events observed in the specimens investigated.

\begin{tabular}{|c|c|c|c|c|c|c|c|c|c|c|c|c|c|c|c|c|c|c|c|c|c|c|}
\hline \multicolumn{4}{|c|}{ Specimen $\mathrm{n}}$. & 1 & 2 & 3 & 4 & 5 & 6 & 7 & 8 & 9 & 10 & 11 & 12 & 13 & 14 & 15 & 16 & 17 & 18 & 19 \\
\hline \multirow{2}{*}{ 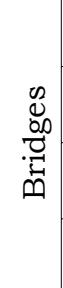 } & \multicolumn{3}{|c|}{ Continuity } & 4 & 4 & 1 & 1 & 1 & 4 & 4 & 1 & 1 & 4 & 2 & 2 & 4 & 4 & 4 & 1 & 2 & 1 & 3 \\
\hline & \multicolumn{3}{|c|}{ Thickness } & 4 & 4 & 3 & 1 & 1 & 4 & 4 & 3 & 3 & 4 & 3 & 4 & 4 & 4 & 4 & 2 & 4 & 2 & 4 \\
\hline \multirow{6}{*}{ 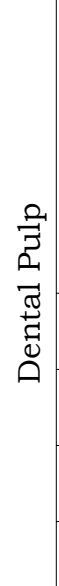 } & \multirow{3}{*}{ 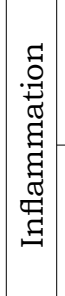 } & \multirow{2}{*}{$\begin{array}{l}\stackrel{0}{ \pm} \\
\stackrel{0}{<}\end{array}$} & Intensity & 1 & 4 & 1 & 1 & 4 & 4 & 4 & 1 & 1 & 4 & 1 & 1 & 4 & 3 & 4 & 1 & 4 & 1 & 1 \\
\hline & & & Extension & 1 & 4 & 1 & 1 & 4 & 4 & 4 & 1 & 1 & 4 & 1 & 1 & 4 & 2 & 4 & 1 & 4 & 1 & 1 \\
\hline & & 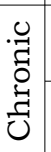 & Intensity & 4 & 4 & 1 & 2 & 4 & 4 & 4 & 2 & 2 & 4 & 2 & 2 & 4 & 4 & 4 & 1 & 4 & 1 & 3 \\
\hline & \multicolumn{3}{|c|}{ Giant cells } & 1 & 4 & 1 & 1 & 4 & 4 & 4 & 1 & 1 & 4 & 1 & 2 & 4 & 2 & 4 & 1 & 4 & 1 & 1 \\
\hline & \multicolumn{3}{|c|}{ Foreign particles } & 1 & 4 & 1 & 1 & 4 & 4 & 4 & 1 & 1 & 4 & 1 & 1 & 4 & 2 & 4 & 1 & 4 & 1 & 1 \\
\hline & \multicolumn{3}{|c|}{ Bacteria } & 1 & 4 & 1 & 1 & 4 & 4 & 4 & 1 & 1 & 1 & 1 & 4 & 4 & 4 & 4 & 1 & 4 & 1 & 1 \\
\hline
\end{tabular}


Briso ALF, Rahal V, Mestrener SR, Dezan Junior E. Biological response of pulps submitted to different capping materials. Braz Oral Res 2006;20(3):219-25.

\section{DISCUSSION}

The primary goal of pulp capping is to keep the integrity of the dental pulp after casual or intentional exposure with utilization of an adequate protection material. Calcium hydroxide was highlighted in the studies of $\mathrm{Eda}^{7}$ (1961) and Holland ${ }^{11}$ (1971), which revealed good outcomes after its utilization for direct pulp capping, both in morphological and histochemical aspects. However, these studies did not employ any other capping material for comparison with calcium hydroxide. It is known that its initial effect on the pulp is destructive ${ }^{10}$, yielding chemical injury caused by hydroxyl ions, which present highly alkaline $\mathrm{pH}$, leading to superficial necrosis of the pulp with mild irritation. This area of necrosis, when the pulp is not protected by a good marginal sealing achieved with restorative materials, may yield failures in the formation of hard tissue $^{5,25}$, which, in the presence of ideal marginal sealing, should present a dentin-like aspect ${ }^{20}$.

The present study made use of $\mathrm{Ca}(\mathrm{OH})_{2}$ P.A. over the area of exposure to evaluate the effect of this substance when chemically pure, since other studies have employed $\mathrm{Ca}(\mathrm{OH})_{2}$ cements, which include other substances in their composition that may interfere with the outcomes.

The importance of a tooth-restoration interface with no gaps was reported by Kanka ${ }^{14}$ (1990), who assigned pulp problems to failures in the sealing of restorations and consequent penetration of bacteria. In the present study, the achievement of poor results with $\mathrm{Ca}(\mathrm{OH})_{2}$ may be related to such occurrence, leading to marginal leakage ${ }^{17}$. It should be mentioned that the glass ionomer material applied on the $\mathrm{Ca}(\mathrm{OH})_{2}$ presents chemical bonding with the tooth structure ${ }^{3}$. However, since this material was applied on the dentin without any surface treatment, its bonding was probably limited to the cohesive resistance of the smear layer, which was not removed by any etchant, thereby limiting the contact required for bonding between the material Fuji II LC and the dentinal tissue.

Moreover, it should be mentioned that the glass ionomer used in this study has resin copolymers in its composition, which indicates that this material may be chemically bonded to the composite resin employed for restoration and consequently may have been displaced due to the polymerization shrinkage of the composite resin, further exposing the pulp tissue to bacterial penetration.

Thus, even knowing about the effectiveness of the adhesive systems in marginal sealing in com- posite resin enamel restorations, we can still find in the literature reports about the occurrence of microleakage in this substrate, considering that restorative procedures in small cavities become even more critical. Hence, we cannot exclude this possibility ${ }^{4,9,23}$.

Bacteria within the pulp tissue could still have come from the dogs' blood stream, since the inflammation due to the dental injury causes vasodilatation and an increase of vessel permeability, making the transport of bacteria through the hematogenic way possible.

It is known that this phenomenon, named anachoresis, consists in the permanence of circulating microorganisms, foreign proteins and other substances in inflammatory areas ${ }^{6}$. By means of this hypothesis, we may deduce that cavity preparations with pulp exposure become favorable to anachoresis, where microorganisms may persist or even collaborate for more bacterial colonizations.

According to Schmitt et al. ${ }^{19}$ (2001), the greatest difficulty for the achievement of success in pulp therapies is the prevention of contamination by bacteria. Contamination through the restorations' margins should thus be avoided for the achievement of a successful treatment. For that purpose, a fundamental aspect for a perfect sealing is the absence of marginal leakage, both at the capping material and at the tooth-restoration interface. However, it should be highlighted that even the best adhesive systems present failures in the sealing of margins of restorations, especially when located in dentinal tissue. Thus, possible failures in sealing may have been involved in the adverse outcomes achieved with $\mathrm{Ca}(\mathrm{OH})_{2}$ in the present study.

On the other hand, MTA presented a higher success rate, and the hard tissue bridges were primarily composed of dentin without areas of necrosis. This material does not contain calcium hydroxide, but rather calcium oxide, which is transformed into calcium hydroxide when in contact with tissue fluids. According to Seux et al. ${ }^{21}$ (1991), it presents some structures that are similar to calcite crystals found in calcium hydroxide. They attract fibronectin, which is generally responsible for cellular adhesion and differentiation. Thus, it is believed that MTA may have an effect similar to that of calcium hydroxide as to the formation of a hard tissue bridge. However, the displacement of the material may be reduced, since it is bonded to the surface irregularities of the cavity preparation. This would also facilitate the construction of the restoration, since it would allow the utiliza- 
Briso ALF, Rahal V, Mestrener SR, Dezan Junior E. Biological response of pulps submitted to different capping materials. Braz Oral Res 2006;20(3):219-25.

tion of etchants and more adequate utilization of the glass ionomer cements. However, considering the 3 cases of pulp necrosis with the presence of microorganisms in one of them, this resistance to displacement was only controlled, and could not be entirely eliminated. It seems to be related with the use of restorative clinical procedures.

Favorable outcomes as to the utilization of mineral trioxide aggregate (MTA) were also found by Pitt Ford et al. ${ }^{18}$ (1996), who investigated the pulp response of monkeys to MTA and calcium hydroxide cement, revealing the formation of a hard tissue bridge in all specimens in the MTA group and occurrence of pulp inflammation in only one specimen. On the other hand, pulps treated with calcium hydroxide cement presented pulp inflammation and the occurrence of hard tissue bridge in only 2 specimens. Faraco, Holland ${ }^{8}$ (2001) conducted a study to compare the actions of calcium hydroxide cement and MTA in 30 teeth submitted to pulp exposure. Both materials were employed for capping and once again the specimens receiving MTA displayed a repair process with the formation of a hard tissue bridge and the absence of inflammation; the results were more favorable than those observed for the group treated with calcium hydroxide cement. Similarly, in an in vivo study, Aeinehchi et al. ${ }^{2}$ (2003) found more effective outcomes with the utilization of mineral trioxide aggregate compared to calcium hydroxide P.A. In this study, evaluation was performed 6 months after capping and the teeth presented a lower occurrence of inflammation, hyperemia and necrosis,

\section{REFERENCES}

1. Abedi HR, Ingle JI. Mineral Trioxide Aggregate: a review of a new cement. J Calif Dent Assoc 1995;23(12):36-9.

2. Aeinehchi M, Eslami B, Ghanbariha M, Saffar AS. Mineral trioxide aggregate (MTA) and calcium hydroxide as pulp capping agents in human teeth: a preliminary report. Int Endod J 2003;36(3):225-31.

3. Alani AH, Toh CG. Detection of microleakage around dental restorations: a review. Oper Dent 1997;22(4):173-85.

4. Carvalho RM, Pereira JC, Yoshiyama M, Pashley DH. A review of polymerization contraction: the influence of stress development versus stress relief. Oper Dent 1996;21(1):1724.

5. Cox CF, Sübay RK, Ostro E, Suzuki S, Suzuki SH. Tunnel defects in dentin bridges: their formation following direct pulp capping. Oper Dent 1996;21(1):4-11.

6. Dezan-Jr E. Indução experimental de anacorese no periápice de dentes após obturação dos canais. Estudo em cães em região geográfica endêmica para leishmaniose [Tese de besides a greater formation of hard tissue bridge and odontoblastic layer.

Thus, the present results confirmed that not only do calcium hydroxide cements present poorer histomorphological outcomes compared to MTA, as revealed in other studies, but so does calcium hydroxide P.A., since it induces a high index of giant cells indicating the permanence of foreign bodies within the pulp tissue, such as dentin scrapings deriving from the action of diamond burs used for cavity preparation or even capping material residues. These particles dispersed within the pulp tissue cause intense macrophagic reaction and their presence hinders the desired repair by producing a chronic inflammatory infiltrate, as observed in a greater proportion of the calcium hydroxide group specimens.

This highlights the importance of conducting further studies on this material, which has encouraging expectations for clinical application.

\section{CONCLUSION}

Within the present conditions and considering the results achieved, it could be concluded that MTA was better (significance level of 1\%) than calcium hydroxide for pulp capping procedures, presenting lower levels of infection and necrosis.

\section{ACKNOWLEDGMENTS}

This research was supported by the State of São Paulo Research Foundation (FAPESP), P. 03/09604-4.

Doutorado]. Bauru: Faculdade de Odontologia da USP; 2001.

7. Eda S. Histochemical analysis of the mechanism of dentin formation in dog's pulp. Bull Tokyo Dent Coll 1961;2:5988.

8. Faraco IM Jr, Holland R. Response of the pulp of dogs to capping with mineral trioxide aggregate or a calcium hydroxide cement. Dent Traumatol 2001;17(4):163-6.

9. Feilzer AJ, De Gee AJ, Davidson CL. Setting stress in composite resin in relation to configuration of the restoration. J Dent Res 1987;66(11):1636-9.

10. Glass RL, Zander HA. Pulp healing. J Dent Res 1949;28(2):97-107.

11. Holland R. Histochemical response of amputed pulps to calcium hydroxide. Rev Bras Pesq Med Biol 1971;4:8395.

12. Holland R, Souza V, Mello W, Nery MJ, Bernabé PFE, Otoboni Filho JA. Healing process of dog's dental pulp after 
Briso ALF, Rahal V, Mestrener SR, Dezan Junior E. Biological response of pulps submitted to different capping materials. Braz Oral Res 2006;20(3):219-25.

pulpotomy and protection with calcium hydroxide or Dycal. Rev Odontol UNESP 1979/1980;8/9:67-74.

13. Holland R, Souza V, Nery MJ, Faraco Junior IM, Bernabé $\mathrm{PFE}$, Otoboni Filho JA, et al. Reaction of rat connective tissue to implanted dentin tube filled with mineral trioxide aggregate, Portland cement or calcium hydroxide. Braz Dent J 2001;12(1):3-8.

14. Kanka $\mathrm{J} 3^{\text {rd }}$. An alternative hypothesis to the cause of pulpal inflammation in teeth treated with phosphoric acid on the dentin. Quintessence Int 1990;21(2):83-6.

15. Main C, Mirzayan N, Shabahang S, Torabinejad M. Repair of root perforations using mineral trioxide aggregate: a long-term study. J Endod 2004;30(2):80-3.

16. Mestrener SR, Holland R, Dezan E Jr. Influence of age on the behavior of dental pulp of dog teeth after capping with an adhesive system or calcium hydroxide. Dent Traumatol 2003;19(5):255-61.

17. Murata SS. Análise histomorfológica de dentes decíduos de cães após biopulpectomia e obturação dos canais com diferentes materiais [Dissertação de Mestrado]. Araçatuba: Faculdade de Odontologia da UNESP; 2002.

18. Pitt Ford TR, Torabinejad M, Abedi HR, Bakland LK, Kariyawasam SP. Using mineral trioxide aggregate as a pulpcapping material. J Am Dent Assoc 1996;127(10):1491-4.

19. Schmitt DDS, Jacob Lee DD, Bogen DDS. Multifaceted use of ProRoot MTA root canal repair material. Pediatr Dent 2001;23(4):326-9.
20. Schröder U. Effects of calcium hydroxide-containing pulp-capping agents on pulp cell migration, proliferation, and differentiation. J Dent Res 1985;64(spec n):541-8.

21. Seux D, Couble ML, Hartmann DJ, Gauthier JP, Magloire H. Odontoblast-like cytodifferentiation of human pulp cells in vitro in the presence of calcium hydroxide-containing cement. Arch Oral Biol 1991;36(2):117-28.

22. Shipper G, Grossman ES, Botha AJ, Cleaton-Jones PE. Marginal adaptation of mineral trioxide aggregate (MTA) compared with amalgam as a root-end filling material: a low-vacuum (LV) versus high-vacuum (HV) SEM study. Int Endod J 2004;37(5):325-36.

23. Shirai K, De Munck J, Yoshida Y, Inoue S, Lambrechts $\mathrm{P}$, Susuki K, et al. Effect of cavity configuration and aging on the bonding effectiveness of six adhesives to dentin. Dent Mater 2005;21(2):110-24.

24. Torabinejad M, Chivian N. Clinical applications of mineral trioxide aggregate. J Endod 1999;25(3):197-205.

25. Ulmansky M, Sela J, Sela M. Scanning electron microscopy of calcium hydroxide induced bridges. J Oral Pathol 1972;1(5):244-8.

26. Zander HA. Reaction of the pulp to calcium hydroxide. J Dent Res 1939;18(4):373-9.

Received for publication on Sep 01, 2005

Sent for alterations on Feb 10, 2006 Accepted for publication on May 17, 2006 